\title{
EVOLUTION OF PEASANT LAND TENURE DURING THE UKRAINIAN REVOLUTION OF 1917-1921
}

\author{
Sergey Kornovenko ${ }^{1}$ \\ Bohdan Khmelnytsky National University of Cherkasy, Ukraine \\ Vitalii Telvak ${ }^{2}$, Vasyl Ilnytskyi ${ }^{3}$ \\ Drohobych Ivan Franko State Pedagogical University, Ukraine
}

\begin{abstract}
The subject of the study is the evolution of peasant land tenure during the period of the Ukrainian Revolution of 1917-1921. The contribution supports the assumption that the Ukrainian revolution of 1917-1921 was a peasant one by its character. The principal agent of Ukrainian history of that period was the peasantry. Peasant revolutionary activity dramatically affected the state of land tenure in Ukraine. It clearly underwent radical changes. The essence of these transformations was the elimination of landlordism and the expansion of the peasant land tenure. The main subject of land relations in Ukraine during the Ukrainian Revolution of 1917-1921 was a peasant landowner. The methodological basis of the study was the concept of the "Great Peasant Revolution", put forward in the scientific works of V. Danilov, T. Shanin. Its main statements were further developed in the latest developments of N. Kovalev, I. Farenii, S. Kornovenko, and other scholars. Peasant revolution of the early twentieth century laid the foundation of all the revolutionary transformations deploying in Ukraine in the first decades of the twentieth century. A socio-cultural approach is the core methodological benchmark of our study. One of the features of the socio-cultural paradigm is a certain universalism, which makes it possible to study cultural, political, economic, and other elements as a whole, as well as consider society as a unity of culture and sociality. Considering these basic principles, the peasantry at the beginning of the twentieth century appears as a complicated socio-cultural phenomenon where a well-established routine, the land, the work on it, peasants are closely interconnected. The peasantry was the conservative basis of civilization, a specific form of culture, which reminded statehood by the way of socio-cultural organization. Peasant economy was a socio-cultural phenomenon, object and subject of agrarian policy, it occupied an important place in the social division of labour as a peculiar microscope; and most importantly it was the structural component of the Ukrainian revolutionary society of that time. The purpose of the paper is to investigate the evolution of peasant land tenure during the period of the Ukrainian Revolution of 1917-1921. The basis of the analysis is the agrarian policy adopted by Bolsheviks, N. Makhno, P. Wrangel. The study of these examples clarifies the evolution of peasant land tenure in the Ukrainian village during the period of the Ukrainian Revolution of 1917-1921. As a result of the study, the following conclusions were substantiated. A deliberate policy of liquidation of large land tenure in Ukraine in 1917-1918 by the Soviet authorities was not carried out. Attempts for its implementation took place in Ukraine only in 1919 and were not successful in the end. The Makhnovists were much more effective in their endeavours. Firstly, they did not provoke resistance from peasants of various wealth; secondly, their policy was introduced before the Bolsheviks came to power; and thirdly, their policy was legalized by the relevant decisions of the congresses. P. Wrangel conducted a policy of liquidation of large land tenure in Ukraine in 1920. In its essence, it was similar to the one of Soviet power and Makhno. At the same time, it varied qualitatively from the Soviet one: 1) it had a more thoughtful, systematic, purposeful character; 2) the Government of the South of Russia managed to move away from declarations and eliminated large land tenure in practice; 3) the future of statehood, for which P. Wrangel fought, was clearly linked with the peasantry; 4) he did not identify private ownership of land with large land tenure. The latter was understood as a component of the institution of private land ownership. P. Wrangel believed that possession, use, and disposal of land were the essence of the peasants' aspirations for land ownership. Therefore, only large land tenure suffered the liquidation.
\end{abstract}

Key words: peasant land tenure, large land tenure, peasantry of Ukraine, peasant ownership of land, state ownership of land.

JEL Classification: R14, P14, H82

\footnotetext{
Corresponding author:

${ }^{1}$ Bohdan Khmelnytsky National University of Cherkasy.

E-mail: s-kornovenko@ukr.net

ORCID: http://orcid.org/0000-0002-6268-2321

${ }^{2}$ Department of World History and Special Historical Disciplines, Drohobych Ivan Franko State Pedagogical University.

E-mail: telvak1@yahoo.com

ORCID: http://orcid.org/0000-0002-2445-968X

${ }^{3}$ Department of Ukraine's History, Drohobych Ivan Franko State Pedagogical University.

E-mail: vilnickiy@gmail.com

ORCID: http://orcid.org/0000-0002-4969-052X
} 


\section{Introduction}

The Ukrainian Revolution of 1917-1921 is a significant event in the history of the Ukrainian nation at the beginning of the twentieth century. In view of this, the scientific interest in it is strengthened and both by domestic and foreign historians (Verstiuk, 2003; Panchuk, 2000; Verstiuk, Holovchenko, Ostashko, Pyrih, Soldatenko, Sokalskyi, 2011; Farenii, 2014). It is quite natural, given the scale and radicalism of the changes caused by this socio-cultural phenomenon. The tendencies not only to identifying the previously unknown or hushed pages of history but also to the conceptual understanding of the Ukrainian revolution of 1917-1921 have become notable in the latter-day historical research (Verstiuk, 2011). In particular, there have been appearing more and more adherents of the concept of "great peasant revolution" at one time represented in the research heritage of V. Danilov and T.Shanin. The concept mentioned has been much referred to at the scientific events of different levels (Revoliutsiinyi protses, 2014; Farenii, 2014; Soldatenko, 2014).

In our opinion, the understanding of the Ukrainian revolution of 1917-1921 as multidimensional and holistic historical and socio-cultural phenomenon seems to be new and reasonable. However, we believe that a peasant component was the most significant one of all its components (Kornovenko, 2014). Accordingly, the peasantry was the most active subject of the Ukrainian revolution of 1917-1921. This gives us the reason to talk about the peasant nature of the Ukrainian revolution. At the same time, this does not contradict the fact that the Ukrainian revolution was the national-democratic revolution in its character.

One of the proofs that the Ukrainian Revolution of 1917-1921 was peasant in its character is that peasant revolutionary activity fundamentally affected the state of land tenure in Ukraine. It underwent radical changes. The essence of these transformations was the elimination of large land tenure, the expansion of the peasant land ownership. The main subject of land relations in Ukraine during the Ukrainian Revolution of 1917-1921 was a peasant owner.

The purpose of the study is to investigate the evolution of peasant land tenure during the Ukrainian Revolution of 1917-1921. The basis of the analysis was the agrarian policy of the Bolsheviks, N. Makhno, P. Wrangel. The study of these examples clarifies the evolution of peasant land tenure in the Ukrainian village during the Ukrainian Revolution of 1917-1921. The achievement of this goal involves solving such research tasks:

1) to reveal the content of the Soviet agrarian innovations in solving the issue of peasant land tenure in 1917-1919; 2 ) to analyse the evolution of peasant land tenure in the theory and practice of the Makhnovists;

3 ) to find out the essence of the transformations of land relations in the policy of P. Wrangel.
The methodological basis of the study was the concept of the "Great Peasant Revolution", proposed in scientific works of V. Danilov, T. Shanin. Its main provisions were further developed in the latest developments of N. Kovalev, I. Farenii, S. Kornovenko, and other scholars. Peasant revolution of the early twentieth century laid the deep foundation of all the revolutionary transformations experienced by Ukraine in the first decades of the twentieth century. A socio-cultural approach is the core methodological benchmark of our study. One of the features of the socio-cultural paradigm is a certain universalism, which makes it possible to study cultural, political, economic, and other elements as a whole, as well as consider society as a unity of culture and sociality. Considering these basic principles, the peasantry at the beginning of the twentieth century appears as a complicated socio-cultural phenomenon where a well-established routine, the earth, the work on it, peasants are closely interconnected. The peasantry was the conservative basis of civilization, a specific form of culture, which reminded statehood by the way of socio-cultural organization. Peasant economy was a socio-cultural phenomenon, object and subject of agrarian policy, it occupied an important place in the social division of labour as a peculiar microscope; and most importantly, it was the structural component of the Ukrainian revolutionary society of that time.

In our study, the term "agrarian policy" is understood as a component of the internal economic policy, which contains socio-economic and socio-political components. The socio-economic part deals with such crucial issues in the life of the peasantry as land reform and the settlement of current agricultural issues: improving land management, increasing agricultural land cultivation, providing farms with agricultural equipment, seed funds, cattle, etc. The socio-political aspect concerns the forms and methods of cooperation between the authorities and the peasantry, the legal status of the peasants.

Sometimes the agrarian policy is identified with the land one. In our view, the land policy is an important component of agrarian, but it concerns more the conditions of agricultural production and not the production itself. Similarly, agrarian and land issues are often considered identical. In our opinion, they correlate with each other as agrarian and land policy, that is, the land issue is a part of agrarian, more concerned with forms of ownership of land than industrial relations. The agrarian question is the question of land ownership forms, types of agricultural enterprises, and the laws of agricultural development. Peasant question - the question of socio-economic, socio-political, legal status of the peasantry, its subjectivization as a part of the Russian imperial socio-cultural organism. 


\section{Soviet agrarian innovations from 1917 to 1919: declarations and realization}

In modern historiography, the proposition that the agrarian factor was among those several determining factors that led to social and political upheavals in the Russian Empire in the early twentieth century is axiomatic. Despite all efforts of the authorities to balance it, before the Ukrainian revolution of 1917, the agrarian issue transformed into an acute socio-economic and socio-political problem. This largely defined it that the Ukrainian revolution of 1917-1921 was peasant by its character. Landlordism was one of its ingredients that on the one hand, most peasants were discontent with and on the other hand, it caused the opposition of the authorities before and during the Ukrainian revolution of 1917-1921. It was its transformation or immunity that were the subjects of fierce debate, defining the nature of the government agricultural initiatives and activities in the early twentieth century and the orientation of the agrarian policies of various political and military forces within the Ukrainian revolution of 1917-1921.

In our opinion, one of the distinctions of the Ukrainian revolution of 1917-1921, is that notwithstanding the fact that its antagonistic participants implacably treated each other; they had the same views and adhered to similar ideas of the solutions of the then acute socio-economic and socio-political issues. The confirmation of our thesis is the attitude of the Bolsheviks, N. Makhno, and P. Wrangel to the idea of landlordism.

Soviet historiography, defending the ideology of the ruling party, consistently emphasized the fact that only the wise leadership of the Bolsheviks under Lenin abolished landlordism within the revolution of 1917-1921. It was supported by citing the "Decree on Land", adopted by the Second Congress of Soviets at the night of 8 to 9 October, 1917, the Law "On Socialization of Land", adopted by the Third Congress of Soviets, January, 23-31, 1918, and other legislative initiatives of the Soviet rule aimed at eliminating private ownership of land in general, and landlordism in particular. Additionally, the thesis that, first, the Soviet agricultural policy was consistent with the fundamental interests of the whole peasantry, and, secondly, no one of the participants of the revolution had distributed more land to the peasants than the Soviets, was imposed (Trapeznikov, 1976; Illereckaya, 1981; Istoriya krestyanstva SSSR, 1986). Thus, the idea that the Bolsheviks were the only political force being able to meet the long-standing aspirations of the peasantry was affirmed. The abovementioned Soviet myth had no place for the other participants of the revolution. In terms of the ideology of those times, it was logical and justified. From the standpoint of historical objectivity and truth, the roles of the opponents were ignored; their image was shaped like that of the goofy subjects of history.

This simplified view of the developments of the Ukrainian Revolution of 1917-1921 was justly criticized by the researchers in the late 1980s - early 1990s.
For example, through citing rather convincing arguments, T. Osipova questioned the thesis that the "Decree on Land" met the interests of all peasants (Osipova, 1990). When it comes to the Ukrainian realities, this document, rather, became the catalyst not of the elimination of landlordism but of the peasants' land squatting and self-redistribution. We believe that the Decree legally originated the liquidation of landlordism, but its results were not legitimized. We are convinced that the elimination of landlordism is a deliberate policy of the government and the authorities, a component of the land policy, which should be comprised of the legislation and of the activities of the competent authorities, aimed at eliminating landlordism, and all this should be accompanied by legitimizing the results.

The policy of the Soviet power in Ukraine in 19171918 aimed at the elimination of landlordism was not coherent. The attempts of its implementation took place in Ukraine only in 1919. It turned into a fiasco. It was recognized by the Soviet researchers (Trapeznikov, 1976). They saw the reason to it in the fact that the Soviet government did not eliminate the landlordism; it was sooner bringing the usage of land under the state rule. The eternal desire of the peasants to own/manage/ use the land was completely ignored by the Bolsheviks. Landlordism was replaced by the state land ownership. This pattern of events significantly weakened the position of the Soviet power in Ukraine (Kulchytskyi, 1996; Kulchytskyi, 1992; Kornovenko, 2005). In fact the Soviet power could not any longer stay in the territory of Ukraine. In fact, on the eve of the offensive of the Armed Forces of South Russia, the Bolsheviks were left without the support from the rear - the peasantry.

\section{Agrarian policy of N. Makhno}

N. Makhno's policy and activities in eliminating landlordism were much more effective. Coming from a peasant environment, N. Makhno surprisingly subtly understood the psychology of the peasants, their aspirations and desires: "In front of me I saw my friends, peasants - those anonymous anarchist revolutionary fighters, who in their lives never knew what it means to fool each other. They were of pure peasant nature, they were difficult to convince of something, but if convinced, if they understood you and believed, and if that belief was not betrayed, they magnified this ideal at every turn, anywhere where it was possible ... We cognized the village from experience..." (Makhno, 1929).

N. Makhno was sure that peasants, feeling desperate in the agricultural policy of the Provisional Government and the Central Rada (Council) demanded to quickly and fairly resolve the land issue. N. Makhno advocated the elimination of private property, the socialization of the land and was against any authorities and advantages of one over another. His plan of actions included four main points: 1) the association of peasants with the 
group formed by N. Makhno; 2) the isolation of the peasants from the influences of the other parties; 3 ) the gradual transfer of power to the locally elected bodies; 4) the formation of the political culture of the peasants, "...so that in their struggle for the land and freedom of self-government [they] ... could rely on themselves..." (Makhno, 1929).

The last item was attached much importance to by the peasant leader. Nestor Makhno knew that only close contacts among him, the force that he represented, and the peasantry would, at least within Hulyai Pole, a town in the south-east of Ukraine, implement the program and meet the eternal desire of farmers. "...To take drastic steps on dispersing government institutions in Hulyai Pole and outlaw private ownership of land, factories, and other businesses we were, alongside with tracing the echo of our movement in urban areas, to approach the peasant masses, make sure of the stability of their revolutionary potential, let the peasants feel that we are close to them and are full-heartedly loyal to those ideas and thoughts that we voice at the meetings and peasant rallies" (Makhno, 1929).

The supporters of NestorMakhnomadetheirprogram provisions public and fixed them in the resolutions of congresses at different levels. Concerning the land issue, which was actively discussed by the delegates of the Second Congress of the representatives of peasants' and workers' councils of 35 districts from the Hulyai Pole territory and the Makhno supporters, there was passed the following resolution: "... the earth belongs to nobody and it may be used only by those who work on it and who handle it, the land should belong to the Ukrainian toiling peasants' use, it should be free of charge and based on the egalitarian and labour standards" (Verstiuk, 1992) Comparing this resolution to the content of the Third Universal, one can see the ideological similarity of two documents, on the other hand - the hostility of the political forces that prepared it, to one another. At the above convention, the delegates who were supporting Makhno put forward such a proposal: "... We only insist that the peasants, who have so far been farmers, should be provided the unconditional right to manage the land the way they want, at least during this single season, otherwise the peasants and the workers will be left without bread. They say that our agriculture is destroyed, the peasants experience the deficit of the farming tools and the like, and I have to say that it is a slight exaggeration. Indeed, some tools and implements are broken, and the households lack horses, but still if the peasants are given land and promised that everything they have toiled will be theirs, then, of course, the land will be sown" (Verstiuk, 1992).

The peasants unreservedly trusted N. Makhno, moreover - they believed in him. I. Herasimenko, the White Guard officer, wrote, "The sympathies of the peasants were on the side of Makhno, and when in the conversation with the member of the Makhno grouping one could openly and sharply criticize Makhno, any angry criticism in the presence of a pro-Makhno peasant could result in the death of a faultfinder" (Volkovynskyi, 1992). The reason for the fanatical devotion to the peasant leader is multifaceted. First, as S. Semanov rightly observes, in Russia, which suffered deep revolutionary shocks, the embittered and impoverished lower classes were dreaming of an earthly paradise and as it is typical of the young people to hurry, to want everything and immediately the anarchism bribed them by its directness and simplicity of plans (Semanov, 2004: 55). Secondly, while the Provisional Government and the Central Council were not decisive in their actions and delayed any of them, and the Bolsheviks had no power, the Makhno people carried out the confiscation and redistribution of the estates of landlords, and thus liquidated landlordism. Thirdly, fighting against all regimes, N. Makhno always and everywhere defended the interests of the peasantry, protecting them from the Austro-German occupation, the Bolsheviks, the Whites, and the Petlurites. Fourth, he knew exactly what the peasants were aspiring at and how to achieve this.

N. Makhno tried to implement the political principles, which he adhered to. June through August of 1917 was a period of active discussions and decision-making by the peasants of the Makhnocontrolled territory of the most important issue the land one. At the May congress in Olexandrivsk, they adopted a resolution, which dealt with the transfer of land, compensation-free, for the use of the toilers, which was reflected in the declaration of the Hulyai Pole Peasants' Union (Makhno, 1929). In June 1917, the villagers refused to fulfil their lease obligation, requiring to deprive landlords and kulaks of the land after the harvest and to divide it among themselves (Makhno, 1929). During the armed assail of L. Kornilov, in Hulyai Pole there took place the Congress of the Soviets, which, among other agenda items, discussed the issues of the practical elimination of landlords and kulaks. The anarchist-communists spoke to the delegates and offered not only to redistribute the land but to organize in the estates free agricultural communes with the participation of the peasants, landowners, and kulaks. If the latter refused they could be offered a redistributed norm of the land to hold their own personal farms (Makhno, 1929). This way Makhno gained significant popularity among peasants and got their support. Nestor Makhno, unlike his opponents who strongly delayed the redistribution of land and were afraid of peasant uprisings, realized that it was impossible to suppress them or somehow postpone, hence he headed the peasant movement and gave the land to those who toiled it. In this respect, he recalled: "...I convened all landlords and kulaks, deprived 
them of their documents on the acquisition of land property. According to these documents, the Land Department made accurate records of all resources of land that belonged to the landlords and kulaks. At the Council of Workers' and Peasants' Deputies, there was organized the Committee of Farmhands and the farmhand movement against the landlords and kulaks was initiated..." (Makhno, 1929).

In mid-August 1917, at the initiative of N. Makhno, who at that time headed a local village council, there was held an inventory of the equipment remaining from the landlords and kulaks: "revolutionary workers were thirsty for action. I offered to my peasants to delegate some persons to the Land committees and hurried to divide the church, landowners' and public lands to be sown by winter crops and to plow, preparing for the spring' (Makhno, 1929). On the 25th of September 1917, he signed a decree of the county council on the socialization of land and its redistribution among the peasants (Volkovinskij, 1991). Not wasting time, the peasants launched the implementation of a newly signed document. "Farmers have actively set to work, but when they went into the field and began to divide the land, it became clear that the land which they had sown by winter crops should be left to each peasant for this year with the recoupment of some sum for the community, so as to equalize public funds spent on social needs, in which those who have neither taken nor cultivated land this year will not pay their share. In general, the peasants took the land that was to be plowed in winter, and redistributed it, despite the threat of state agents" (Makhno, 1929).

So, as the said above confirms, the policy of the liquidation of landlordism in Ukraine, which was implemented by N. Makhno, firstly, was more effective than the Soviet one. It did not cause resistance from the peasants of different wealth. Secondly, it was implemented before the Bolsheviks' coming to power; its results were legalized by the relevant decisions of the congresses.

The policy of the liquidation of landlordism in the territory, controlled by the Russian Army in 1920, was carried out by P. Wrangel. Essentially it was similar to that of the policy of the Soviets and Makhno. At the same time, it differed from the Soviet one in the following: 1) it was more thought-out, systemic, and purposeful; 2) the government of the South managed to move away from declarativeness and eliminated landlordism; 3) the future of the statehood for which the Russian Army fought, P. Wrangel undoubtedly linked with the peasantry; 4) he did not identify private ownership of land with landlordism. Landlordism was understood as a component of private ownership of land. P. Wrangel believed that to possess, use, and dispose of land was the essence of the eternal aspirations of the peasants to own the land. Therefore, it was only landlordism that underwent the liquidation.

\section{Transformation of land relations in the policy of $P$. Wrangel}

P. Wrangel conducted a policy of liquidation of large land tenure in Ukraine in 1920. In essence, it was similar to the one of Soviets and Makhno. At the same time, it varied qualitatively from the Soviet one: 1) had a more thoughtful, systematic, purposeful character; 2) The Government of the South of Russia managed to move away from declarative and in practice eliminate large land tenure; 3 ) the future of statehood, for which P. Wrangel fought, he clearly linked with the peasantry; 4) he did not identify private ownership of land with large land tenure. The latter was understood as a component of the institution of private ownership of land. P. Wrangel believed that possession, use and disposal of land - the essence of the aspirations of peasants to land ownership. Therefore, the only large land tenure suffered the liquidation.

The agrarian legislation of the Government of South Russia was published on May 25, 1920 (old style). A package of documents included the following: "Notification of the government of the land issue", "The injunction on the earth", "Regulations on the transfer by the Government of the lands belonging to the state, the State Land Bank, and privately owned lands of agricultural use to the property owners, who have cultivated the land", and "The interim on land institutions" (TsDAHOU, F. 57, Acc. 2, Case 428; Vrangel, 1992).

In the government report, the essence of the agrarian reform was clarified: the land should be given to its owners who work on it. The reform was determined by the purpose of P. Wrangel's government: 1) to protect the land management in the form, in which it was found at the time of innovation; 2) to pass to the masters who work on the land, the state-owned and privately owned lands used for agricultural purposes; 3 ) to create in the village decent conditions for the economic development and increasing prosperity, for the peasants not to suffer from encroachments and uncertainty.

The communication also dwelt on the mechanism for the implementation of the agrarian reform: the land was alienated from the former owners, but they kept their right on some lands, the size of which, depending on regional characteristics, was determined by the local land agencies comprised of peasants. The government approved the decisions of these agencies. The informational communication identified the categories of land that were subject and not subject to alienation. The latter included: 1) the lands acquired through the Peasants' Land Bank and which did not exceed the established norm; 2) pieces and plots allocated for the hamlets; 3) parish plots, estates, and highly cultured lands; 4) lands of the agricultural research and education institutions; 5) the plots of land that did not exceed the specified size. 
The lands which were alienated were fixed for those peasants who were cultivating those lands at the time of the release of both - the law, and the informational communication. The size of those lands was determined by the local land agencies, but could not be less than the standards set by the Peasants' Land Bank. This distribution was fixed by the act that recognized the unquestionable ownership. On its basis, the documents were published and they finally fixed the ownership of land by new owners after payment of all of its cost to the state. The lands, though without their immediate delimiting, passed in a lifelong, hereditary property for ransom because there was to be assuredness that the lands would be in the property of the economically strong owners who could handle them (TsDAHOU, F. 57, Acc. 2, Case 428, p. 75-79).

P. Wrangel believed that peasants themselves, through the established organs of power, were to solve the agrarian question. The authorities of the Crimea, which was under the power of the White Guard, designing the control and management system, revised the role, place, and significance of the peasant initiative and selforganization. The township and rural structures were considered to be the support for the local authorities, the foundation on which the frame of the renewed Russian statehood was being erected. This position provided that the leading role in the implementation of the government initiatives in the political and economic field belonged to the peasant self-government bodies. That is why the government of the "White" Crimea did not interfere with the peasant initiative of restoring rural and township gatherings, the institution of the village and township foremen. At least, we have not found any written memory of it in the sources employed for the research. On the contrary, historical sources indicate that the commanders of the military units located in the counties of the Northern Tavria received clear instructions from the Chieftain of how to behave in relations with the authorities of the peasant selfgovernment. Thus, the heads of the civil departments of the army pledged to fully support the activities of the township and village chiefs, and the meetings convened by them (DARF, FR. 3801, Acc. 1, Case 2, p. 24-24 zv.). It found support in the "Provisional Regulations on land institutions".

That way P. Wrangel and his supporters tried to build such a model of "dialogue" with the peasantry, in which the agrarian question, relevant for the latter, would be solved by the peasantry through the "county and district land boards, comprised of peasants" (Svedeniya, 1928). The government authorities relegated a much more modest role and functions to themselves. As G. Glinka noted in his letter to V. Maklakov, the "governmental authorities do not make any orders to the local authorities when it comes to the land issues, they only help, assist, and prevent the intrusion of any anti-state elements..." (Pismo, 1928). The telegram to the chief of the Dzhankoy district ran: "Give full support to the provincial land mediator in gradual establishing in townships the electoral county gatherings for the elections of the county land councils." The Simferopol provincial land mediator B. Schleifer got similar instructions concerning the pre-election work in Simferopol, Evpatoria, and Perekop counties (DARF, FR. 355, Acc. 1, Case 5, p. 81, 83). Soon, when his ideas were proved by experience, at the end of July 1920, the Commander-in-chief issued the order, by which the posts of the rural commandants were cancelled. By this, the authorities eliminated the impact of the militaries on the work of government in rural areas (RDVA, FR. 101, Acc. 1, Case 174, p. 41 zv.).

Township and county land councils, whose decisions were approved by the provincial land council, became those bodies that took over the legitimate functions of liquidation of landlordism within the Wrangel agrarian reform. The important mission of conducting the preliminary work of determining the conditions of the future distribution of agricultural land among the owners, who worked on it, was commissioned to the county council. Among the priority tasks to implementing which the activities of those bodies were directed, there was the task to determine the location, composition, and quantity of the lands that were leased, not cultivated by the owners, and were without proper care. In addition, it was necessary to find out who, in what sequence, and in what amount is entitled to receive the land. Thus, alpha and omega of the township land councils' activities were: 1 ) the registration of the fund of agricultural land, which was to be distributed primarily; 2) the development and submission for the approval by the county councils the documents on the size of plots assigned to new owners; 3 ) compiling the list of persons who have been offered to withdraw the land; 4) land ownership; 5) determining the maximum limits that remained for the former owner; 6) estimates the average yield for the past 10 years (DAARK, FR. 1668, Acc. 1, Case 1a, p. 50-51).

The formation of the local land administration, which had rather extensive powers, was, in our opinion, a significant step forward in attracting peasants to the nation-building. This legally fixed the intention of the Crimean White Guard leaders to make the peasants an effective force in carrying out the agrarian reform, as well as in nation-building of the generally updated model of the Russian statehood.

It should be noted that during the liquidation of landlordism N. Makhno also widely attracted the peasant initiative and their independent activities. Thus, speaking against a centralized bureaucratic power, old or new bureaucracy, he made great efforts to organize the Peasants' Union, which would create conditions for the peasants approaching the land issue on their own initiative and declaring it socialized. It was Makhno's ideal of peasant freedom: they were to decide on their 
own and cope with everything on their own. In addition, through the Union, the peasantry would actively join the revolution, spread and deepen it, clear the way for its development, and would define its essence. This also reflected the understanding by the peasants of the complex social and political vicissitudes of 1917-1921. The decision on the distribution and the procedure itself were carried out, in accordance with N. Makhno's doctrine, by the peasants, that is - by their delegates to the township convention of land committees. That convention pointed out the landlords' estates and their lands for the organization there of voluntary agricultural communities (Lobachov, 2001; Mahno, 1929).

Most of the lands of large landowners' estates during the Wrangel's agrarian reform were subject to alienation and redistribution of them into private property among the peasants who were in need of additional patches of land. In particular, in the estate of Azekah belonging to B. Beckman and located in the Tav-Badrak township, by the Township land board decision 60 tenths ( 60 tenths of a square kilometre) of the arable land and 91 tenths of the uncultivated land passed into the peasants' ownership. In the same township, 403 tenths of the field arable land and 155 tenths of the pastures from S. Safronov's "Molla Al" estate passed to their new owners (TsDAHOU, F. 5, Acc. 1, Case 322, p. 3). By the decision of the Kabariy township, the lands of the estates whose owners did not cultivate the land on their own, were subject to the immediate redistribution. First of all, it concerned such estates as: Tetiy, Bink, Kuchuk, Toksaba, and Ekaterinovka (DARF, FR. 355, Acc. 1, Case 5, p. 4).

The distribution of the landlords' estates was especially actively performed in the front-line districts, such as the Dniprovsky one. The Novo-Troitsk township land council in the presence of the engineer Rudin passed the decision about the alienation of 600 tenths of the land in Ginsburg's estate and transferring the land into private ownership of 18 lessees. The Hromov township land council was planning to transfer to private ownership of 60 tenants 2 thousand of the tenths from Faltz-Fein's estate; 2 thousand of the tenths of the leased land from Sheiner estate was transferred into the private ownership of 85 peasants who worked on that land, and 320 tenths from Mashkalov's estate were passed to the 15 lessees who cultivated it (Doklad, 1928).

The positive socio-political resonance among the peasantry was caused by the distribution of land in the Atmanay estate. By the decision of the township land council, 500 tenths of its land were allotted for 22 peasants (DARF, FR. 355, Acc. 1, Case 5, p. 173). The peasants from the Yekaterinoslav province who came for salt in the Ukluh estuary and to Atmanay could not believe that the landlord's land had become the property of the local peasants. Then they were taken to the fields where they saw the surveyors. The latter were paving the limits of the allotted land patches (Doklad, 1928). The Yekaterinoslav peasants were shocked. They saw firsthand that P. Wrangel did not only declare but also realized in practice the agrarian reform. Against the background of social and political instability and socio-economic crisis in Soviet Ukraine, the situation in Northern Tavria and the Crimea had changed to advantage. The Yekaterinoslav farmers couldn't but see that.

Thus, P. Wrangel did not only declare the withdrawal of the excess land from the big landowners but also implemented this idea into practice across the county and township land councils. The minimum of the arable land was left to the landowners. Most of the land was redistributed among the peasants for repurchase. According to our estimates, which coincide with the data suggested by V. Tsvetkov (Tsvetkov, 2006) the land was redistributed for peasants in different ways in more than 20 large estates. In average, the size of the peasants' land, according to N. Ross' information grew by 100 tenths or more, and that of landlords decreased from 100 to 600 tenths (Ross, 1982). In our opinion, considering the processed historical sources, the adjustments made to the rules of the land distribution on October 4, 1920, the maximum of landlords' lands should be limited by 400 tenths while that of the peasants' lands ranged from 60 to 250 tenths.

\section{Conclusions}

The Ukrainian Revolution of 1917-1921 was of a peasant character. The active subject of Ukrainian history of the period was the peasantry. Peasant revolutionary activity has dramatically affected the state of land tenure in Ukraine. It has undergone radical changes. The essence of these transformations was the elimination of large land tenure, the expansion of the peasant. The main subject of land relations in Ukraine during the Ukrainian Revolution of 1917-1921 was a peasant owner.

A deliberate policy of liquidation by the Soviet authorities of large land tenure in Ukraine in 1917-1918 was not carried out. Attempts for its implementation took place in Ukraine only in 1919 with no success. The Bolsheviks were not the only ones who declared the abolition of large land tenure as a priority task for agrarian reform. N. Makhno was one of the first who not only declared but also practically eliminated great land tenure in Ukraine during the revolution of 1917-1921. We believe that the Makhnovist were much more effective in conducting agricultural policy comparing with Soviets. Firstly, they did not provoke resistance from peasants of various wealth; secondly, their policy was introduced before the Bolsheviks came to power; and thirdly, their policy was legalized by the relevant decisions of the congresses. P. Wrangel conducted a policy of liquidation of large land tenure in Ukraine in 1920. In its essence, it was similar to the one of Soviet power and Makhno. At the same time, it varied qualitatively from the Soviet one: 1) it had a 
more thoughtful, systematic, purposeful character; 2) The Government of the South of Russia managed to move away from declarations and eliminated large land tenure in practice; 3 ) the future of statehood, for which P. Wrangel fought, was clearly linked with the peasantry; 4) he did not identify private ownership of land with large land tenure. The latter was understood as a component of the institution of private land ownership. P. Wrangel believed that possession, use, and disposal of land were the essence of the peasants' aspirations for land ownership. Therefore, only large land tenure suffered the liquidation.

If the Soviet liquidation of large land tenure was transformed into state expropriation of lands, then Makhno and Wrangel aimed at giving lands to peasants with the further legitimization of this process.

Prospects for further developments. The further study of the influence of peasant revolutionism on the land policy of national governments during the period of the Ukrainian Revolution of 1917-1921 is substantiated.

\section{References:}

DARF - Derzhavnyi arkhiv Rosiiskoi Federatsii [State Archive of the Russian Federation].

DAARK - Derzhavnyi arkhiv Avtonomnoi Respubliky Krym [State Archive of the Crimean Autonomous Republic]. RDVA - Rosiiskyi derzhavnyi voiennyi arkhiv [The Russian State Military archive].

TsDAHOU - Tsentralnyi derzhavnyi arkhiv hromadskykh obiednan Ukrainy [Central State Archive of Public Organizations of Ukraine].

Verstiuk V., Holovchenko V., Ostashko T., Pyrih R., Soldatenko V., Sokalskyi V. (2011). Narysy istorii Ukrainskoi revoliutsii 1917-1921 rokiv [Essays on the History of the Ukrainian revolution of 1917-1921]. U 2-kh kn. Kn. 1. Kyiv: Naukova dumka. 390 p. (in Ukrainian)

Verstiuk V. (2003). Peredmova [Foreword]. Ukrainskyi natsionalno-vyzvolnyi rukh. Berezen-lystopad 1917 roku: Dokumenty i materialy [Ukrainian national liberation movement. March-November 1917: Documents and Materials] / uporiad.: V. Verstiuk (ker.) ta in. Kyiv. P. 5-12. (in Ukrainian)

Verstiuk V.F. (1992). Makhnovshchyna: seliansko-povstanskyi rukh na Ukraini (1918-1921) [The Makhno Ideas: the Peasant Insurgency in Ukraine (1918-1921). Kyiv. 368 p. (in Ukrainian)

Volkovinskij V.N. (1991). Nestor Ivanovich Mahno [Nestor Ivanovich Makhno]. Voprosy istorii [Historical issues]. № 9-10. P. 38-58. (in Russian)

Volkovynskyi V.M. (1992). Batko Makhno [Makhno]. Kyiv: Tovarystvo «Znannia» Ukrainy. 48 p. (in Ukrainian) Vrangel P. (1992). Vospominaniya barona P. Vrangelya [Memoirs of Baron Wrangel]: v 2-h tt. T. 1. Moskva: Terra. 480 p. (in Russian)

Doklad Tavricheskogo gubernskogo posrednika po zemelnym delam nachalniku upravleniya zemledeliya i zemleustrojstva 4 oktyabrya $1920 \mathrm{~g}$. [The report of the Tavrian Provincial Agent on the Land Issues to the Head of the Agriculture and Land Management Administration of October, 4, 1920] / Agrarnaya politika Vrangelya [P. Wrangel's Agrarian Policy]. Krasnyj arhiv [Red Archive]. 1928. T. 1. P. 80-93. (in Russian)

Illereckaya E. (1981). Agrarnyj vopros: proval agrarnyh programm i politiki neproletarskih partij v Rossii [The Agrarian Issue: Failure of the Agrarian Programs and the Policies of the Non-Proletarian Parties in Russia]. Moskva: Nauka. 165 p. (in Russian)

Istoriya krestyanstva SSSR. Istoriya sovetskogo krestyanstva (1986) [History of the Peasantry of the USSR. The History of the Soviet Peasantry]: v 5 t. T. 1. Krestyanstvo v pervoe desyatiletie sovetskoj vlasti. 1917-1927 [The Peasantry in the First Decade of the Soviet power. 1917-1927] / pod red. V. S. Herstobitova. Moskva: Nauka. 455 p. (in Russian)

Kornovenko S.V. (2005). Ahrarna polityka bilshovykiv v ukrainskomu seli v 1919 r. (do prychyn tymchasovykh nevdach) [Agricultural Policy of the Bolsheviks in the Ukrainian Village in 1919 (the Reasons for Temporary Setbacks)]. Ukraina Soborna [The Soborna Ukraine]. Pereiaslav-Khmelnytskyi. Vyp. 2. P. 81-85. (in Ukrainian)

Kornovenko S.V. (2014). Ukrainska revoliutsiia 1917-1921 rr.: selianskyi faktor [The Ukrainian Revolution of 1917-1921: a Peasant Component]. Ukrainskyi selianyn [Ukrainian peasant]. Vyp. 14. P. 142-146. (in Ukrainian) Kulchytskyi S. (1996). Komunizm v Ukraini: pershe desiatyrichchia (1919-1928) [Communism in Ukraine: the first decade (1919-1928)]. Kyiv: Osnovy. 306 p. (in Ukrainian)

Kulchytskyi S.V. (1992). Komunistychna doktryna i sproby yii realizatsii v Radianskii Ukraini u 1919-1920 rr. [The Communist Doctrine and THE Attempts on its Implementation in Soviet Ukraine in 1919-1920]. Istorychni zoshyty [Historical notebooks]. № 8.40 p. (in Ukrainian)

Lobachov V. (2001). Byl li batka Mahno anarhistom? [Was Makhno an anarchist?]. Nauka i religiya [Science and Religion]. № 1. Pp. 22-24. (in Russian)

Mahno N. (1929). Russkaya revolyuciya na Ukraine [The Russian Revolution in Ukraine]: V 3-h kn. Kn. 1. (Ot marta 1917 g. po aprel 1918 god) [(From March 1917 to April 1918)]. Parizh. 216 p. (in Russian)

Osipova T. (1990). Obmanutyj klass [The Deceived Class]. Rodina. № 10. Pp. 24-25. (in Russian)

Panchuk A. (2000). Istoriohrafiia Zakhidno-Ukrainskoi Narodnoi Respubliky (1918-2000 rr.) [Historiography of the Western Ukrainian People's Republic (1918-2000)]: avtoref. dys. ... kand. ist. nauk [Manuscript of the thesis ... Candidate of historical sciences]. Kyiv. 20 p. (in Ukrainian) 
Pismo Nachalnika Upravleniya zemledeliya i zemleustrojstva Glinki V. A. Maklakovu 16 sentyabrya 1920 g. [The Letter of the Head of the Agriculture and Land Management Administration, Glinka, to V.A. Maklakov, September, 16, 1920] / Agrarnaya politika Vrangelya [P. Wrangel's Agrarian Policy]. Krasnyj arhiv [Red Archive]. T. 1. 1928. P. 65-68. (in Russian)

Revoliutsiinyi protses 1917-1920 rokiv: vytoky, zmist, znachennia. Zbirnyk naukovykh prats za naslidkamy teoretychnoho seminaru, orhanizovanoho kafedroiu arkhivoznavstva, novitnoi istorii ta spetsialnykh istorychnykh dystsyplin i Naukovym tovarystvom istorykiv-ahrarnykiv 13 chervnia 2013 r. [Revolutionary Process of 1917-1920: origins, content, meaning. Collection of scientific papers on the results of the theoretical seminar, organized by the Department of Archival Studies, modern history and special historical disciplines and scientific societies historians agrarian June 13, 2013]. Cherkaskyi nats. un-t; Nauk. tov. istorykiv-ahrarnykiv [Bohdan Khmelnytsky National University of Cherkasy, Scientific Society of Historians-Agrarians]. Cherkasy: Vertykal, 2014. 62 p. (in Ukrainian)

Ross N. (1982). Vrangel v Krymu [Wrangel in the Crimea]. Frankfurt-na-Majne: "Posev”. 362 p. (in Russian)

Svedeniya ob osushchestvlenii zemelnogo zakona Vrangelya 25 maya 1920 goda k 15 sentyabrya [Information on the Implementation of P. Wrangel's law on the Land of May, 25, 1920 as of September, 15]. Agrarnaya politika Vrangelya [P. Wrangel's Agrarian Policy]. Krasnyj arhiv [Red Archive]. 1928. T. 1. P. 61-65. (in Russian)

Semanov S. (2004). Mahno. Sudba atamana [Makhno. The Ataman's Fate]. Moskva. 320 p. (in Russian)

Soldatenko V.F. (2014). Chynnyk "ukrainskoho khliba" v Hromadianskii viini (1917-1920 rr.) [The "Ukrainian bread” Factor in the Civil War (1917-1920)]. Ukrainskyi selianyn [Ukrainian peasant]. Vyp. 14. P. 156-162. (in Ukrainian)

Trapeznikov S.P. (1976). Leninizm i agrarno-krestyanskij vopros [Lenynyzm and the Agro-Peasant issue]: V 2-h tomah. T. 1. Moskva: Mysl. 567 p. (in Russian)

Farenii I.A. (2014). Pro pravomirnist kontseptsii "Velykoi selianskoi revoliutsii" V.P. Danylova [On the legitimateness of the V.P. Danilov's concept of the "Great Peasant Revolution"]. Ukrainskyi selianyn [Ukrainian peasant]. Vyp. 14. P. 162-166. (in Ukrainian)

Cvetkov V. (2006). General-lejtenant baron P.N. Vrangel [Lieutenant-General, Baron P.N. Wrangel]. Beloe dvizhenie. Istoricheskie portrety [The White Movement. Historical Portraits]. Moskva: Astrel. P. 346-383. (in Russian) 